\title{
Town centre management models: A European perspective
}

\author{
Jose Andrés Coca-Stefaniak ${ }^{\mathrm{a}, *}$, Cathy Parker $^{\mathrm{b}}$, Simon Quin ${ }^{\mathrm{c}}$, Roberto Rinaldi ${ }^{\mathrm{d}}$, John Byrom ${ }^{\mathrm{e}}$ \\ a School of Creative Enterprise, London College of Communication, University of the Arts London, Elephant E Castle, London, England \\ ${ }^{\mathrm{b}}$ Institute of Place Management, Manchester Metropolitan University Business School, Manchester, England \\ ${ }^{\mathrm{c}}$ Association of Town Centre Management, London, England \\ ${ }^{\mathrm{d}}$ Department of Business Economics, University of Bergamo, Bergamo, Italy \\ e School of Management, University of Tasmania, Launceston, Australia
}

\section{A R T I C L E I N F O}

\section{Article history:}

Received 19 May 2008

Received in revised form 2 December 2008

Accepted 14 December 2008

Available online 22 January 2009

\section{Keywords:}

Town centre management

SME retail

Europe

\begin{abstract}
A B S T R A C T
Town centre management (TCM) has evolved considerably over the last 25 years in terms of both its purpose and methods. Whilst most reviews of TCM to date have focused on its development within the Anglo-Saxon world (typically North America and the United Kingdom), comparatively little attention has been given to other models of place and town centre management that have emerged across Europe. This paper seeks to redress the balance by exploring the relevance of other models from a number of European countries, which were researched using a case study approach and conceptualised within a framework which seeks to classify TCM schemes by their funding sources and structural formality. It is argued that, despite their lower budgets or lack of formal recognition, other models of TCM such as informal place management schemes or hybrids of formal and informal TCM schemes can often be just as effective in delivering positive outcomes for urban communities.
\end{abstract}

(c) 2008 Elsevier Ltd. All rights reserved.

\section{Introduction}

It has become commonly accepted that places, however broadly or narrowly defined, need to be managed actively (Oc and Tiesdell, 1998; McGill, 1998; Symes and Steel, 2003; van Dijk, 2006; Seisdedos, 2008) to ensure their sustainability (Girardet, 2006). This is in line with Elkington's (1994) conceptual "triple bottom line" principle of economic, social and environmental performance. Nowhere is this more apparent than at the level of individual towns and cities - in spite of the abundance of definitions that this process has generated in the urban management literature (Mattingly, 1994) as growing megacities compete for prosperity on a global scale (Marcuse and Van Kempen, 2000) whilst striving to retain a local identity (Borja and Castells, 1997; Czarniawska, 2002).

Over the last quarter of a century, TCM has emerged as a practical response to the complexities of urban revitalisation (Page and Hardyman, 1996) at the local level with valuable contributions through area-based marketing (Stubbs et al., 2002; Warnaby et al., 2005), sustainable development (Banister, 1998), the engagement of disadvantaged socio-economic groups (Woolley, 2000; Guy and Duckett, 2003), frameworks for place making and regeneration (Otsuka and Reeve, 2007a) and the development of inte-

\footnotetext{
* Corresponding author. Tel.: +44 02075146942.

E-mail addresses: a.coca@lcc.arts.ac.uk (J.A. Coca-Stefaniak), c.parker@mmu.ac. uk (C. Parker), simon.quin@atcm.org (S. Quin), robertorinaldi@email.it (R. Rinaldi), john.byrom@utas.edu.au (J. Byrom).
}

grated area-based public-private sector partnerships (Jones et al., 2003; Lloyd et al., 2003: de Nisco et al., 2008).

Against this backdrop, we present an overview of how TCM has evolved in Europe in the recent past. By taking a pan-European perspective, this study seeks to widen previous debates - generally centred around British perspectives of the concept - by exploring parallels in the development of TCM across different national contexts, as suggested by Reeve (2004), following a transnational comparative study approach.

In the next section, the concept of TCM, first in the British context and then in its different European derivations, is considered. Following this, models of TCM are considered and a matrix containing European TCM schemes is presented. This matrix (after Medway et al., 2006), seeks to elucidate the contribution of various types of schemes (including, for example, informal SME retailer-led schemes) to the future of TCM in the UK and continental Europe. The matrix is utilised, in the following section, to illustrate specific case studies of individual schemes from Italy, Spain, the UK and Austria which were informed by questionnaires translated into four languages and answered by practising town centre managers. The purpose of this is to establish whether it offers a useful and workable tool for academics and practitioners. The final section outlines how TCM might best evolve into the future.

\section{Defining town centre management}

In the early days of its development in the United Kingdom, TCM was seen primarily as a response to external factors and 
consisted of "a comprehensive response to competitive pressures, which involves development, management and promotion of both public and private areas within town centres, for the benefit of all concerned" (Wells, 1991, p. 24). Guy suggested a more specific vision of this role, with TCM incorporating:

"many of the hitherto usually separate concerns of town planning, leisure, public health and publicity departments. Secondly, it implies a co-operative rather than confrontational relationship with the private sector" (Guy, 1993, p. 36)

Other (British) authors have built on this to suggest a more strategic marketing facet to TCM. For instance, Warnaby et al.'s widelycited definition suggests that it involves:

"the search for competitive advantage through the maintenance and/or strategic development of both public and private areas and interests within town centres, initiated and undertaken by stakeholders drawn from a combination of the public, private and voluntary sectors" (1998, pp. 17-18)

More recently, the concept of TCM has also been defined through the pivotal strategic management role that each town centre manager plays in:

"gathering and sharing market information, enabling stakeholders to work together in the strategic planning process, setting up formal and informal communication and social networks between partners, training the town's stakeholder employees to implement the regeneration strategy and maintain a marketing orientation, and evaluating success, in order to both motivate all involved and to assess progress" (Whyatt, 2004, p. 352)

In the UK, the Association of Town Centre Management (ATCM) - the leading body representing town centre management schemes across the United Kingdom and the Republic of Ireland with 550 members in 2008 - defines (town/city) centre management as:

"a co-ordinated pro-active initiative designed to ensure that our town and city centres are desirable and attractive places. In nearly all instances the initiative is a partnership between the public and private sectors and brings together a wide-range of key interests" (nd, unpaginated)

Parallel to the development of TCM in the United Kingdom, similar initiatives began to arise in Spain (AGECU, nd; Martmn Rojas, 1997; Dirección General de Comercio Interior, 1998; Sánchez del Rí10, 2001), Italy (Moras et al., 2004; Zanderighi, 2004; Codato et al., 2005), Sweden (Sandahl and Lindh, 1995; Forsberg et al., 1999; Svenska Stadskärnor, nd), Austria (Stadtmarketing Austria, nd), France (Cossardeaux, 1999), Norway (Norsk Sentrumsforum, 2008), Belgium (AMCV, nd), Germany (BCSD, nd) and other European countries. Although there was much in common with the UK factors initiating TCM, e.g. the need to revitalise town centres which faced decline due to the emergence of alternative retail formats such as out-of-centre and edge-of-centre shopping centres and retail parks (Dawson and Burton, 1999), the means to achieve this were altogether different. Unlike in the UK, most Spanish, Italian and French TCM schemes, for example, were led from the outset by small and medium sized independent retailers (Molinillo Jiménez, 2001). This led to a greater focus on retailing, customer service and the development of local trade associations. Although a single generally accepted definition is yet to be agreed upon in Spain following various attempts at the local and regional levels (e.g. Pascual, 1995; Frechoso Remiro, 2000; Torres Outón, 2005), the concept of centros comerciales urbanos or centros comerciales abiertos first coined by Castresana (1999) - both of which can be translated as "retailer-led town centre management schemes" - has been defined geographically and functionally (i.e. in terms of retailing) as:

"[a scheme aimed to manage] retail outlets in a section of the town or city, normally bound by a number of streets, which tends to coincide with the historical old town where, traditionally, street markets existed and, therefore, most trade used to take place outdoors" (translated from Vilariño et al., 2002, p. 35).

In spite of this spatial definition of a typical TCM scheme, the conceptual description of this management model would not be complete without reference to the importance of the high level of cooperation that must exist between retailers, other small businesses in the service sector (e.g. restaurants, cafes, entertainment outlets, and so forth) and local authorities. It is through such cooperation that the model can achieve its full potential in terms of the facilitation of an integrated approach to the management of public and private space through effective public-private partnerships (Rovira Lara, 2000).

In line with this philosophy, a similar model of retailer-led TCM has emerged in Italy under the name of centro commerciale naturale, which has been defined as:

"an aggregation of small sized retail shops located in a homogeneous area of the historic city centre that, through a proper company scheme, position themselves in a privileged position with the town council for the development of common strategies ... not only from the commercial competitiveness point of view, but above all from that of the peculiarity of the retail framework to safeguard and valorise, through the reinforcement of the business structure, the urban places of interaction, liveability and socio-environmental balance" (translated from Valente, 2004, p. 894)

Unlike its Spanish and Italian counterparts, the French TCM model, reported by Molinillo Jiménez (2001), based originally on the Vitrines de retailer-led formula (e.g. Vitrines de Mulhouse - the Retailers of Mulhouse), relies on the creation of a public-private partnership to finance the position of the town centre manager. This hybrid model has been linked by Cossardeaux (1999) to a "French variation of the British town centre management model" (translated from Molinillo Jiménez, 2001, p. 34).

Overall, there are various major themes that are common across the European definitions of TCM reviewed above - a common purpose, working in partnership and the presence of a mix of stakeholders (both public and private). However, differences are clearly apparent between the UK definitions of TCM and the French, Italian, and Spanish ones. The continental European approaches are dependent upon the involvement of retailers and other town centre small businesses, with the aggregation of these businesses being the major objective. This is in contrast to the UK approach, which typically makes explicit reference to the building of competitive advantage for town and city centres (e.g. through better quality of life for residents, diversity in the retail and leisure offer, attractions for visitors, etc.) being the raison-d'être for TCM.

\section{Models of town centre management}

Whilst a review of the different definitions of TCM is helpful in establishing the various European interpretations of the concept and its current state of development (in light of the fact that a formal definition does not exist in many countries), it tells us little about the structure and operations of TCM. These are now reviewed.

Warnaby et al. (1998, p. 19) "believe that the criteria of organizational structure and resource are central to a proper understand- 
ing of the initiation and development of town centre management schemes". Furthermore, Warnaby et al. (1998) examine a temporal dimension as important in the initiation and development of TCM schemes, and identify four stages. The first is the conception stage, where the idea of having a TCM scheme is mooted. This is followed by the infancy stage. Here the local authority typically plays the leading role. The third stage is the growth stage where an ad hoc partnership manages the scheme. The last stage, maturity, will see the creation of a formal partnership where the influence of the private sector may predominate.

The TCM typology developed by Warnaby et al. (1998) is built from the experience of UK towns and cities and therefore may not explain the development of TCM schemes in Europe and beyond. Furthermore, Warnaby et al.'s (1998) stages of development do not always 'hold true' outside of the UK where the TCM initiative frequently starts from a small retailer-led scheme (e.g. Spain or Italy) or from a strong formal public-private partnership (e.g. Sweden).

Reeve (2004) presents some interesting criticisms of British TCM schemes. Referring to the public-private partnership aspect of TCM, for example, he notes, "there are concerns that TCM is driven by commercial values, and is acquiring powers that are not as democratically accountable as those traditionally held by local authorities" (Reeve, 2004, p. 134). Reeve contends that private sector business interests, especially those of the leading multiple retailers, have lobbied for a new urban management approach which is "more responsive to its interests" (p. 135).

Zanderighi (2004) explores the different urban models of governance that exist within the Italian context and identifies two macro models. The first, a centralised commercial management model, is typified by the presence of a real estate interest. It replicates the management of a traditional shopping mall (i.e. the scheme can control the tenant mix and offers, under contract, and provides some collective services, such as cleaning or marketing). An example of this type of governance model would be the West End in London, which is managed by the Shaftesbury Estate. The second is a network model, where the governance of the scheme is much less structured, as it is brought about by a dialectic process and a shared vision. There are two practical aspects of this dichotomy: the latter model is associative in nature (it needs group oriented behaviours), but it suffers from the problem of 'free-riders' (Briffault, 1999; Forsberg et al., 1999); whilst the former has a contractual nature in which some or all of the support and funding is obligatory. By exploring the Italian context, Zanderighi (2004) recognises that, given the individuality of each city centre, a 'ready made' TCM model is unlikely to work in a given location. Nevertheless, analysis of the governance of TCM structures can provide some guidelines in starting and developing initiatives.

With the advent of the business improvement district (BID) concept - a funding mechanism for town centre management first developed in North America (Hoyt and Gopal-Agge, 2007) and based on mandatory contributions from businesses located in an area which go towards its management and maintenance - within the UK, a matrix of urban management schemes has been developed by Medway et al. (2006) (see Fig. 1). In common with Warnaby et al. (1998), Reeve (2004) and Zanderighi (2004) a key component of the Medway et al. (2006) matrix is the identification of who (the public or private sector) is funding the scheme. The other continuum used to develop the matrix is the degree of formality inherent in the scheme's structure (following Reeve, 2004). Whilst the matrix is concerned specifically with the classification of UK TCM schemes, the addition of the formal/informal continuum allows for the inclusion of any urban management scheme. In order to establish the applicability of the Medway et al. (2006) matrix in a European context, we present four case studies from various schemes across Europe that illustrate each of the matrix's quadrants (see Fig. 2). The cases were chosen for their ability to provide both contrasts and similarities with respect to the management of the urban fabric (Hartley, 2004).

\section{The private-informal scheme: Cesena, Italy}

Cesena has a population of 92,000 inhabitants and is situated in the Emilia-Romagna region of northern Italy. CesenaInCentro was created as a small retail-led TCM scheme in 2003, in a similar

\section{EXTENT OF FORMALITY}

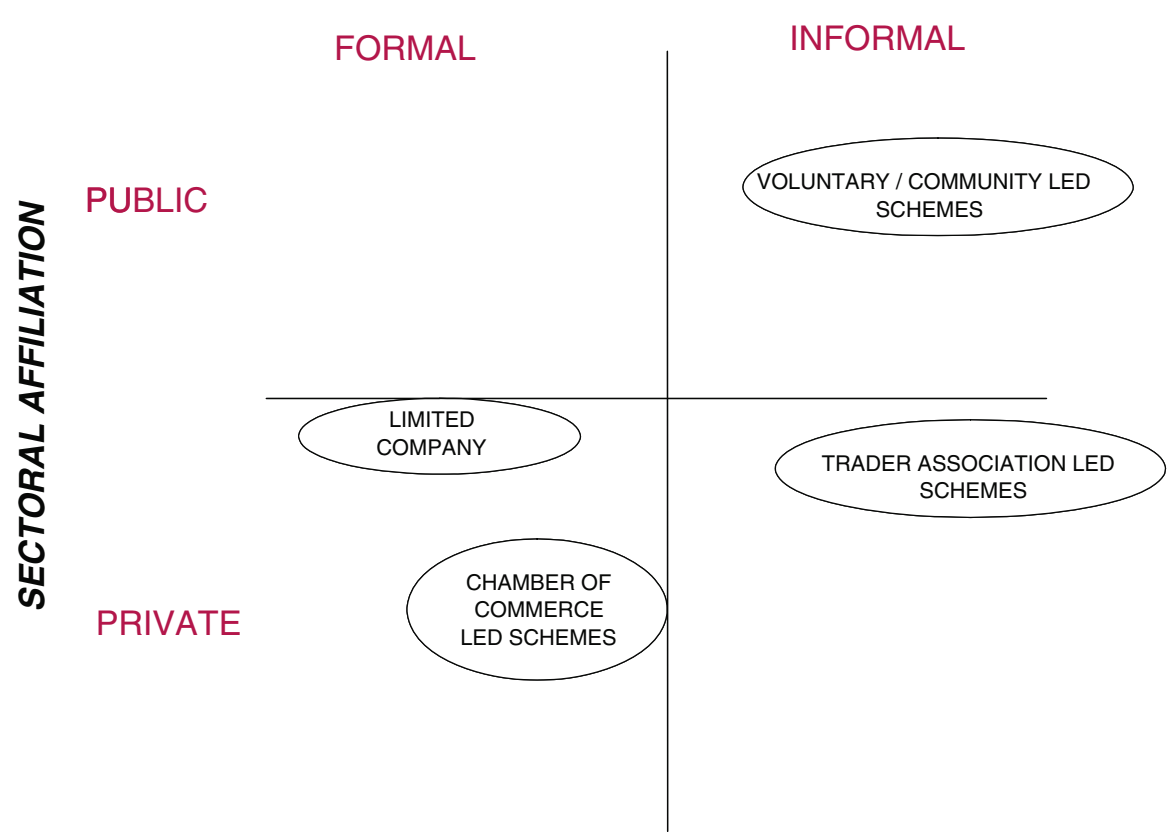

Fig. 1. A structural matrix of UK urban management source: adapted from Medway et al. (2006). 


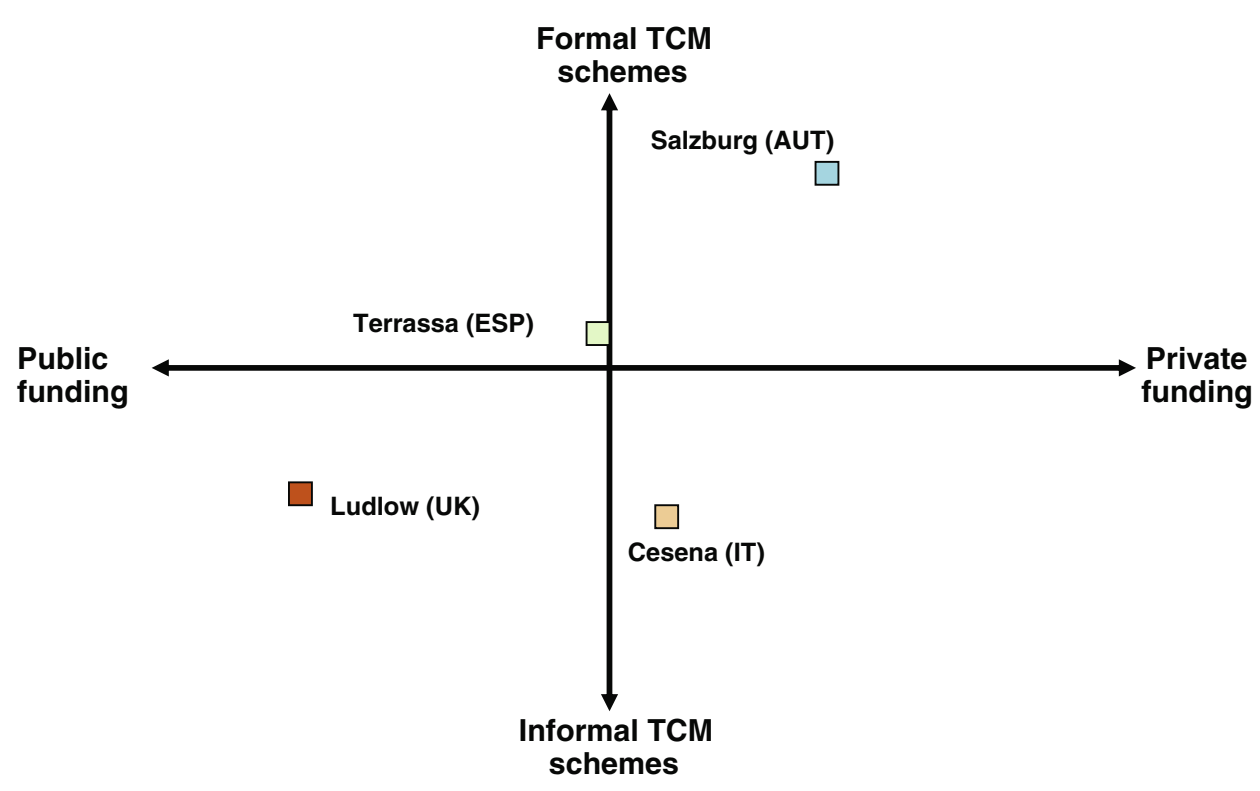

Fig. 2. Classification of European TCM schemes source: adapted from Medway et al. (2006).

fashion to other TCM schemes in Southern Europe such as Granollers in Spain (Coca-Stefaniak et al., 2005) or Novi Ligure in Italy (Coca-Stefaniak et al., 2008), which reflects the utilitarian approach to TCM that appears to prevail in these countries. CesenalnCentro was established to counteract the growing trend of reduced footfall in the town centre attributed to the growth of large out-of-town shopping centres and the development of other city centres located nearby. The project was a result of a strategic alliance between Cesena's small local retailers and two of Italy's largest national retail trade associations - ConfCommercio and Confesercenti. Today, it encompasses the city's historic centre, which is enclosed by 14th century walls and includes a limited traffic zone. CesenalnCentro prides itself on its bottom-up approach to decision-making.

Although CesenaInCentro does not charge membership fees, contributions from its members represent $30 \%$ of its annual budget. The remaining funding is provided in equal measure by the Cesena Town Council and its Chamber of Commerce. The funding is not 'ring fenced' in any way, which allows for a greater degree of autonomy and flexibility in the organisation of TCM activities, which are aimed at promoting the local economy as well as cultural events. CesenaInCentro has taken an activity-led approach to TCM that has been targeted at, and supported by, the town's various stakeholder groups. However, non-contributing businesses ('free-riders') remain a problem that may have to be addressed through a progressive formalisation of the scheme and the appointment of a dedicated town centre coordinator in the future.

\section{The public-formal scheme: Terrassa, Spain}

Situated in the north-eastern Spanish region of Catalonia and 30 kilometres from Barcelona, Terrassa's history stretches back to the Roman Empire where it played an important role as a trading post. In the 19th century Terrassa became known as a leading textile manufacturing centre. This industry prevailed as a key economic driver for the area until the 1970s and left many well preserved heritage landmarks such as textile mills, mill workers' residential districts and fine Modernist buildings. The decline of the textile industry in the late 20th century led to diversification of the economy of Terrassa towards one that was more service-based.
Today, Terrassa has a population of 200,000 distributed across 36 urban neighbourhoods. However, like many other Spanish urban centres, Terrassa began to experience the homogenising forces of globalisation in the early 1990s, with the development of several off-centre supermarkets and shopping malls. This had a detrimental effect on smaller retail businesses based in the city centre and signalled a progressive change in the shopping habits of the area's residents in a similar manner to nearby Granollers (Coca-Stefaniak et al., 2005). In view of this, Terrassa City Council, the Generalitat de Cataluña (Catalan Autonomous Regional Government), the Terrassa Chamber of Commerce, and the Terrassa Retail Trade Association signed a joint agreement in 1999 to create a TCM scheme for the economic revitalisation of the historic town quarter of Terrassa.

The scheme was named Comerç Terrassa Centre and was implemented across an area of the city that has a population of 13,000 and 1257 businesses. Forty-one per cent are in the hospitality sector and a further $40 \%$ are retail outlets. The initiative started with an annual budget of $€ 150,000$, with the Terrassa Retail Trade Association (a not-for-profit organisation) as lead partner contributing just under $50 \%$ of the funding. Other funding partners included Caixa Terrassa (a local financial institution with privatepublic capital), which provides a venue for meetings and a small financial contribution, as well as public sector partners such as the Generalitat de Cataluña, the Terrassa City Council and the Terrassa Chamber of Commerce, whose contributions represented $40 \%, 8 \%$ and $2 \%$, respectively.

The Comerç Terrassa Centre initiative was embedded in a much wider strategy for the urban revitalisation of the city centre, led by Terrassa City Council with a total budget of $€ 4,720,000$. This became the first building block towards a wider initiative called Terrassa Centre - a public-private partnership established in 2006 (with a majority of combined capital and resources from the public sector) with the aim of providing an integrated management service to all the socio-economic stakeholders of Terrassa's historic centre. Following the early successes of the Comerç Terrassa Centre initiative, it soon became apparent that an improved (regenerated) area would not only result in a higher level of physical urban attractiveness and economic activity but also higher maintenance and operational costs. In order for these improvements to become sustainable, it was necessary for the business community to increase its involvement in the decision-making surrounding future 
plans for the town centre through the Terrassa Centre public-private partnership.

The scheme continues to make progress towards its objective of $100 \%$ private sector funding by 2012 . Nonetheless, major challenges still remain including the presence of 'free-rider' businesses. Despite the partnership's best efforts to secure payment of membership fees from all businesses in the town centre, the proportion of 'free-riders' currently stands at $50 \%$. Although current legislation in Catalonia does not allow for the implementation of compulsory membership levy initiatives such as the BID model, steps are being taken in this direction by local authorities and the Generalitat de Cataluña in order to establish the amendments required to Catalan law to enable the implementation of this model. In the meantime, the hybrid model pursued by Terrassa Centre is recognised as being one of the most innovative currently in operation in Spain.

\section{The public-informal scheme: Ludlow, United Kingdom}

Ludlow lies just east of the Welsh border and is one of Britain's finest medieval towns. During the 16th and 17th centuries, the town served as the administrative capital of Wales, attracting numerous wealthy and influential new residents, and during the 18 th century it succeeded in sustaining a prominent role as a regional centre and fashionable resort. By the late 19th and early 20th centuries Ludlow's popularity had waned with the impact of the agricultural depression and two World Wars. Today it is the main administrative and service centre for South Shropshire and its main centre of employment.

Ludlow was the first British town to achieve Cittàslow recognition in 2003. Cittàslow is an international network of small towns (less than 50,000 inhabitants) that share the same philosophy to pursue a sustainable form of eco-government at the local level (Knox, 2005). The Cittàslow initiative was created originally in Italy and has strong links with the Slow Food movement (Mayer and Knox, 2006). The Ludlow Cittàslow strategy has provided a framework, in conjunction with other policies such as Local Agenda 21, for improvements to be made in areas such as infrastructure, urban fabric, local products, hospitality and environmental issues. This overarching framework has allowed the development of a plan for a place management initiative designed by the local community for all the different stakeholders of Ludlow. The initiative follows the principles of social entrepreneurship in a somewhat unique fashion, with the on-going support of the local authority. The authority adopted a visionary organic approach to growth, foreseeing that the initial informal structure may, in time, develop into a more formal scheme with legal recognition and statutes. Ludlow was selected as one of eight pilots across England in the Agora programme led by Manchester Metropolitan University Business School and the Association of Town Centre Management, which was funded by the European Social Fund's Equal programme. The Agora programme was designed to support community-led approaches to town centre management. The Ludlow Agora project adopted the following strategic objectives:

- To improve open spaces in the town centre.

- To set up a social enterprise organisation to manage the town centre.

- To instigate a 'pride-of-place' community-led initiative.

Ludlow Town Council and its Cittàslow Ludlow Committee are the lead partners in the embryonic Ludlow Agora TCM scheme. The Cittàslow Ludlow Committee consists of: South Shropshire District Council's Conservation, Planning, Regeneration and Environment departments, the Ludlow Marches Market Town Initiative, Ludlow 21, Ludlow Chamber of Trade and Commerce, Churches To- gether, Age Concern, Ludlow Assembly Rooms, the Civic Society, the Youth Forum, and representatives from the community at large. Businesses wanting to become a member of the scheme are required to subscribe to the Cittàslow ethos. They must also undertake to become actively involved in the local community, taking responsibility for matters such as the cleanliness of the area around their premises and supporting initiatives such as the Christmas lights, 'Late Night Ludlow' and other events. By operating its TCM scheme through the principles of social enterprise, Ludlow is taking a decisive step towards involving the community as active stakeholders. This is considered to be an effective and genuine way of improving the town's vitality and viability in terms of improved quality of life, community empowerment, the robustness of decision-making, place attachment, place identity and community pride.

\section{The private-formal scheme: Salzburg, Austria}

Located in western Austria and with a population of 150,000 , Salzburg has been inexorably linked with art and music as a result of being the birthplace of Wolfgang Amadeus Mozart in 1756. Its annual 'Salzburg Festival' takes place in July and August. The city's location, at a crossroads between Germany, Italy, France and Hungary, has enabled it to prosper as a retail and tourist destination. With its high amount of retail floorspace per capita, Salzburg has the biggest sales turnover in Austria, although the city centre has had to compete with large off-centre retail developments, including low-price factory outlets.

In 2003, and following a number of previous attempts at revitalising the city centre led by its own small and medium-sized retailers, the Tourismusverband Salzburger Altstadt (TSA, Salzburg Old Town Tourism Association) was founded as a public body, following a vote by potential members. Today, the TSA city centre management scheme is operated by Altstadt Salzburg Marketing $\mathrm{GmbH}$ (ASMG). It is a limited company with shares held by the TSA (49\%), Salzburg City Cooperative (33.6\%) and retail trade associations (17.3\%). Therefore, although TSA is a public body which works in close cooperation with Salzburg City Council, 57\% of the scheme's core funding comes from the private sector using a scheme similar to the BID model. Compulsory business membership fees are in place and the scheme also charges a business tax levy, which is raised by the City Council and passed on to TSA.

The scheme is governed by an executive committee comprising 20 members. All strategic decisions are made by this committee through submissions from its managing director. Whilst Salzburg City Council holds four permanent seats on the committee, their members do not have voting rights on financial issues. TSA also prides itself on its inclusiveness, with all business sectors fully represented in the scheme's decision-making at executive level, although it is yet to engage actively with the area's residents. TSA faces many of the challenges of similar schemes (BIDs) operating in the UK and the USA. These include pressure from retailers and other businesses for a return on investment from their membership fees; and their desire to see that the scheme responds to the increasing competition from out-of-town factory shopping centres.

\section{Discussion and conclusions}

The preceding case studies have shown that the structural matrix of UK urban management is also directly applicable as a tool to classify and analyse TCM schemes across other European settings. The axes of funding sources and the degree of formality are key components of the TCM schemes under study, regardless of location, purpose and degree of retailer involvement. Through 
the presentation of case study evidence, the variety of definitions and models outlined in this paper suggest that TCM, far from reaching a stage of homogenisation, after more than a quarter of a century of existence; continues to grow in an organic fashion. Rather than passing through defined stages (Warnaby et al., 1998), the structure and resourcing of the partnerships considered here change with time. For example, Cesena now has a not-forprofit limited company structure (a Società Consortile Cooperativa in the Italian legal framework), which is led by a board of trustees elected by members of the scheme.

From the cases presented, town centre management remains a "response to competitive pressures" (Wells, 1991, p. 24) or the delivery of local solutions to local problems, whilst, at the same time, being cognisant of the role of global trends in consumer behaviour, trade and the environment (Fernández Güell, 2006). Such trends can challenge the sense of identity of entire cities like Barcelona or Madrid (Luna-Garcia, 2003). The growth of new retailing formats (for instance those located out-of-town or edge-oftown) and changes in consumer behaviour were all common competitive pressures facing our case study schemes. One of the strategic assets of traditional town and city centres is their uniqueness (Charlesworth, 2005; Landry, 2008). Therefore it is important that TCM schemes promote and develop this asset. There may well be innate dangers in the spread of 'good practice' if it serves to standardise the activity of TCM. We believe the matrix shown in Fig. 2 is a useful tool in promoting analysis and reflection. Rather than adopting a 'one size fits all' approach, it allows for a more nuanced approach to TCM scheme development.

Whether TCM schemes can evolve to tackle the competitive pressures of tomorrow remains to be seen. Issues such as climate change (Betsill and Bulkeley, 2002), the widening gap between rich and poor (Atkinson and Bridge, 2005), human migration (Penninx et al., 2004), and rising levels of obesity (Ellaway et al., 2005) are already affecting European towns and cities. Nevertheless, it is only in Ludlow, one of our four case studies, that one can see any evidence of the TCM scheme attempting to widen its remit into issues such as improving quality of life and addressing environmental issues.

In his review of TCM in the UK, Reeve (2004, p. 137) commented that "retail interest has tended to dominate many schemes" and the TCM schemes in Cesena, Terrassa, and Salzburg are certainly focussed upon activities of benefit to the retail sector. Nevertheless, there are wider benefits to other stakeholders, such as, for example, the regeneration and maintenance of an historic area as apparent in the protection of local Catalan heritage in Terrassa (see also Otsuka and Reeve, 2007b). It should also be noted that this article is limited to the experience of four centres. There are other published accounts that describe the societal benefits of other retail-led or focussed TCM schemes (for example, the case of Granollers as documented by Coca-Stefaniak et al., 2005). This demonstrates the value of adopting a case-study approach when researching TCM. An analysis of the distinguishing elements of each situation, and comparison with a wide range of case study examples, may help to find the best town centre solutions. "Asking the question, what is good TCM? requires research capable of capturing long-term achievements and trends, and comparing places with one another" (Reeve, 2004, p. 146).

In the future, the question of what makes good place management may be more apt, as, internationally, there are a number of other approaches to the management of urban areas, such as Business Improvement Districts, Community Business Centres, Neighbourhood Renewal Schemes, Suburban Centre Improvement Schemes, Mainstreet Programmes, Market Town Inititatives, Business Area Improvement schemes and Trade Improvement Zones. In addition, to these more 'formal' schemes, there are likely to be hundreds of thousands of informal and voluntary groups, across the world trying to make places better. For example, Keep Australia Beautiful has been presenting its 'Tidy Town' Awards for 40 years. What started as an award for environmental cleanliness has now expanded in scope to recognise community sustainability, environmental stewardship, heritage protection and uniqueness.

Conceptually, it might well be the case that the time has come for TCM to reinvigorate itself by continuing (or in some cases, starting) to look outwards rather than inwards and learn from developments in place management (Stuart-Weeks, 1998; Walsh, 2001). Far from being a break-away philosophy of how to manage towns and cities, place management shares common roots with TCM, although it tends to have more flexibility in terms of the area that it can be implemented in. Places can be as big or as small as their inhabitants define them (Hull et al., 1994; Jorgensen and Stedman, 2006), because the boundaries of these areas are often set by inhabitants themselves rather than by a public body or institution. This flexibility, driven by the direct empowerment of the communities that reside in a given locale (Boyce, 2000), has often resulted in place management models being particularly successful at managing the needs of disadvantaged groups in both rural and urban environments. Indeed, the organic modularisation of areas offered by place management, where the boundaries of a place can grow or shrink to reflect the feelings and needs of its stakeholders, would appear to be one of its key contributions to delivering services to those that live or work in those locations, or visit them.

The inherent flexibility afforded by place management, both philosophically and in practical terms, would not only allow TCM to offer better value to its stakeholders but, just as importantly, it would encourage a larger degree of cross-pollination of the profession from other fields such as shopping centre management, neighbourhood management, community planning, social entrepreneurship, tourism, marketing, retailing and local government.

Crucially, through its emphasis on engendering a sense of belonging amongst communities and stakeholders, a place management approach to TCM could encourage greater participation of people (including the young, the elderly, immigrants, and socio-economically disadvantaged groups) in decision-making processes which affect their area and others beyond it. In turn, as boundaries grow with a greater feeling of belonging to regions or countries, rather than just a neighbourhood or town, decisionmaking would also benefit from a higher level of robustness at regional and national levels as more people understood the consequences of local interventions for the socio-economic fabric of a town's catchment area and its wider region.

The matrix utilised in this paper offers any type of place management scheme, both established and nascent, from any country, a way to analyse the distinguishing elements of their situation and to learn from both similar and different cases. This recognises that TCM is "not a solution which merely needs to be given the right tools" (Reeve, 2004, p. 146). We believe trends in globalisation, which may also affect TCM itself, in terms of homogenising the concept or its definition, should be resisted from within the profession so as to prevent the adoption of 'me too' approaches that could ultimately lead to the increased standardisation of places.

\section{References}

AGECU (nd) Asociación Española de Gerentes de Centros Urbanos, <http:// www.agecu.net/> (accessed 25 April 2008).

AMCV (nd) Association du Management de Centre-Ville, <http://www.amcv.be/> (accessed 27 December 2005).

ATCM (nd) What is town centre management? <http://www.atcm.org/about/whatis-tcm.php> (accessed 25 April 2008).

Atkinson, R and Bridge, G (2005) Gentrification in a Global Perspective. Routledge, London.

Banister, D (1998) Barriers to the implementation of urban sustainability. International Journal of Environment and Pollution 10(1), 65-83. 
BCSD (nd) Bundesvereinigung City- und Stadtmarketing Deutschland e V, <http:// www.bcsd-online.de> (accessed 25 April 2008).

Betsill, $\mathrm{M}$ and Bulkeley, $\mathrm{H}$ (2002) Cities and Climate Change. Routledge, London.

Borja, J and Castells, M (1997) Local and Global: The Management of Cities in the Information Age. Earthscan, London.

Boyce, J., 2000. The Moree place management project, Australian Institute of Criminology Occasional Seminar, 5 June 2000. <http://www.aic.gov.au/ conferences/occasional/boyce.pdf $>$ (accessed 25 April 2008).

Briffault, R (1999) A government for our time? Business improvement districts and urban governance. Columbia Law Review 99(2), 365-477.

Castresana, J (1999) Nuevas concepciones del urbanismo comercial - los centros comerciales abiertos. Distribución y Consumo 48, 35-44.

Charlesworth, E (2005) City Edge: Case Studies in Contemporary Urbanism. Elsevier, London.

Coca-Stefaniak, J A, Parker, C, Barbany, A, Garrell, X and Segovia, E (2005) Gran Centre Granollers - city, culture and commerce. International Journal of Retail E Distribution Management 33(8/9), 685-697.

Coca-Stefaniak, J A, Stasi, F, Codato, G, Franco, E and Roberts, G (2008) Reclaiming customers through retailer-led TCM scheme in Italy. Journal of Place Management and Development 1(1), 115-124.

Codato, G., Franco, E., Kotval, Z., Mullin, J.R., 2005. City center revitalization: a comparative assessment. Paper presented at the Association of European Schools of Planning Conference, Vienna, 13-17 July.

Cossardeaux, J (1999) L'émergence du town management. Les Echos 20, 51. September.

Czarniawska, B (2002) A Tale of Three Cities or the Glocalization of City Management. Oxford University Press, Oxford.

Dawson, J and Burton, S (1999) Evolución del comercio minorista en Europa. Distribucion y Consumo 43, 25-47.

de Nisco, A, Riviezzo, A and Napolitano, M R (2008) The role of stakeholders in town centre management: guidelines for identification and analysis. Journal of Place Management and Development 1(2), 166-176.

Dirección General de Comercio Interior (1998) Centros Comerciales Abiertos, Centro de Publicaciones y Documentación del Ministerio de Economía y Hacienda, Madrid.

Elkington, J (1994) Towards the sustainable corporation: win-win-win business strategies for sustainable development. California Management Review 36(2), 90-100.

Ellaway, A, Macintyre, S and Bonnefoy, X (2005) Graffiti, greenery and obesity in adults: secondary analysis of European cross sectional survey. British Medical Journal 331, 611-612.

Fernández Güell, J M (2006) Planificacion Estrategica de Ciudades, Reverte, Barcelona.

Forsberg, H, Medway, D and Warnaby, G (1999) Town centre management by cooperation: evidence from Sweden. Cities 16(5), 315-322.

Frechoso Remiro, J C (2000). Centros comerciales abiertos en Castilla y León. Paper presented at the VII Congreso de Economía Regional de Castilla y León, Soria, <http://www.jcyl.es/jcyl/cee/dgeae/congresos_ecoreg/CERCL/1351.pdf> (accessed 25 April 2008).

Girardet, H (2006) Creating Sustainable Cities. Green Books, Totnes.

Guy, C (1993) Town centre investment and management. Papers in Planning and Research, No. 143, Department of City and Regional Planning, University of Wales, Cardiff.

Guy, C and Duckett, M (2003) Small retailers in an inner city community: a case study of Adamsdown, Cardiff. International Journal of Retail \& Distribution Management 31(8), 401-407.

Hartley, J (2004) Case study research. In Essential Guide to Qualitative Methods in Organizational Research, C Cassell and G Symon (eds.), pp. 323-333. Sage, London.

Hoyt, L and Gopal-Agge, D (2007) The business improvement district model: a balanced review of contemporary debates. Geography Compass 1(4), 946-958.

Hull, R B, Lam, M and Vigo, G (1994) Place identity: symbols of self in the urban fabric. Landscape and Urban Planning 28(2-3), 109-120.

Jones, P, Hillier, D and Comfort, D (2003) Business improvement districts in town and city centres in the UK. Management Research News 26(8), 50-59.

Jorgensen, B S and Stedman, R C (2006) A comparative analysis of predictors of sense of place dimensions: attachment to, dependence on, and identification with lakeshore properties. Journal of Environmental Management 79(3), 316-327.

Knox, P L (2005) Creating ordinary places: slow cities in a fast world. Journal of Urban Design 10(1), 1-11.

Landry, C (2008) The Creative City: A Toolkit for Urban Innovators. Earthscan, London.

Lloyd, M G, McCarthy, J, McGreal, S and Berry, J (2003) Business improvement districts, planning and urban regeneration. International Planning Studies 8(4), 295-321.

Luna-Garcia, A (2003) Cities of Spain, localities on the edge of an identity breakdown. Cities 20(6), 377-379.

McGill, R (1998) Urban management in developing countries. Cities 15(6), 463-471.

Marcuse, P and Van Kempen, R (2000) Globalizing Cities: A New Spatial Order? Blackwell, Malden.

Martín Rojas, F (1997) Potenciación de los centros urbanos como espacios comerciales abiertos. Distribución y Consumo 41, 130-135.

Mattingly, M (1994) Meaning of urban management. Cities 11(3), 201-205.
Mayer, H and Knox, P L (2006) Slow cities: sustainable places in a fast world. Journal of Urban Affairs 28(4), 321-334.

Medway, D, Warnaby, G, Byrom, J, Parker, C (2006) Urban management schemes and structures in the United Kingdom. Unpublished paper.

Molinillo Jiménez, S (2001) Centros comerciales de área urbana - estudio de las principales experiencias extranjeras. Distribución y Consumo 57, 27-45.

Moras, G, Codato, G, Franco, E., (Eds.) (2004). L'Approccio Integrato Alla Qualificazione Urbana - Modelli e Strategie di Urbanistica Commerciale, Celid, Torino.

Norsk Sentrumsforum (2008) Norsk Sentrumsforum: Samarbeid mellom Norske bysentrumsorganisasjoner, http://www.norsk-sentrumsforum.no/ (accessed 25 April 2008).

Oc, T and Tiesdell, S (1998) City centre management and safer city centres: approaches in Coventry and Nottingham. Cities 15(2), 85-103.

Otsuka, N and Reeve, A (2007a) Town centre management and regeneration: the experience of four English cities. Journal of Urban Design 12(3), 435-459.

Otsuka, N and Reeve, A (2007b) The contribution and potential of town centre management for regeneration: shifting its focus from 'management' to 'regeneration'. Town Planning Review 78(2), 225-250.

Page, S J and Hardyman, R (1996) Place marketing and town centre management: a new tool for urban revitalisation. Cities 13(3), 153-164.

Pascual, E (1995) El proceso de creación y gestión de los centros comerciales abiertos. Actas del Congreso Internacional de Comercio Alimentario Especializado y Mercados Municipales, Barcelona, 15-17 June.

Penninx, R, Martiniello, M and Vertovec, S (2004) Citizenship in European Cities Immigrants, Local Politics and Integration Policies. Ashgate, London.

Reeve, A (2004) Town centre management: developing a research agenda in an emerging field. Urban Design International 9(3), 133-150.

Rovira Lara, A (2000) Propuestas y modelos para la gestión estratégica de los centros urbanos desde la cooperación publica y privada. Gestión y Análisis de Politicas Publicas 19, 19-34.

Sánchez del Río, R (2001) Centros comerciales abiertos - una estrategia de mejora del atractivo urbano y del nivel de competitividad de la actividad terciaria en las ciudades. Distribución y Consumo 48, 43-52.

Sandahl, J and Lindh, C (1995) Impact of improving the attractiveness of town centres. Transport Policy 2(1), 51-56.

Seisdedos, G (2008) Cómo Gestionar las Ciudades del Siglo XXI: Del City Marketing al Urban Management. FT-Prentice Hall, Barcelona.

Stadtmarketing Austria (nd) Stadtmarketing Austria: dachverband für stadtmarketing und citymanagement. <http://www.stadtmarketingaustria.at> (accessed 25 April 2008).

Stuart-Weeks, M (1998) Place management: fad or future? Presentation to an Open Forum at the Institute of Public Administration Australia (NSW Division), State Library, Sydney, 20 August.

Stubbs, B, Warnaby, G and Medway, D (2002) Marketing at the public/private sector interface; town centre management schemes in the south of England. Cities 19(5), 317-326.

Svenska Stadskärnor (nd) Svenska Stadskärnor - värda att utvecklas! <http:// www.svenskastadskarnor.se/> (accessed 25 April 2008).

Symes, M and Steel, M (2003) Lessons from America: the role of business improvement districts as an agent of urban regeneration. Town Planning Review 74(3), 301-313.

Torres Outón, S M (2005) El comercio local apuesta por los centros comerciales urbanos o abiertos. Paper presented at the III Congreso de Economía de Galicia, Vigo, 1-2 December.

Valente, M (2004) Il Centro Commerciale Naturale per la Riqualificazione Socioeconomica dei Centri Storici. Disciplina del Commercio e dei Servizi, Maggioli Editore, Rimini.

van Dijk, M P (2006) Managing Cities in Developing Countries: The Theory and Practice of Urban Management, Edward Elgar, Cheltenham.

Vilariño, J P, Torres Outón, S M, Mesías Grangel, A, Soage Loira, M (2002) Horizonte comercial del caso histórico I, <http://www.seminariocarlosvelasco.org/ control/files/archivos_pdf/subpublicaciones/sp16-01_10_04-14_33_55-pm.pdf> (accessed 25 April 2008).

Walsh, P (2001) Improving government's response to local communities - is place management an answer? Australian Journal of Public Administration 60(2), 3-12.

Warnaby, G, Alexander, A and Medway, D (1998) Town centre management in the UK: a review, synthesis and research agenda. International Review of Retail, Distribution and Consumer Research 8(1), 15-31.

Warnaby, G, Bennison, D and Davies, B J (2005) Marketing town centres: retailing and town centre management. Local Economy 20(2), 183-204.

Wells, I (1991) Town centre management: a future for the High Street. Geographical Papers, No. 109, University of Reading, Reading.

Whyatt, G (2004) Town centre management: how theory informs a strategic approach. International Journal of Retail \& Distribution Management 32(7), 253346.

Woolley, H (2000) Town centre management awareness: an aid to developing young people's citizenship. Cities 17(6), 453-459.

Zanderighi, L (2004) Commercio Urbano - e Nuovi Strumenti di Governance. Il Sole 24 Ore, Milano. 